\title{
The International Institute of Tropical Forestry: Antecedents and present influences on forest entomology in Puerto Rico ${ }^{1}$
}

\author{
Kevin D. Carlin ${ }^{2}$
}

J.Agric. Univ. P.R. 101:25-31 (2017)

\begin{abstract}
An overview of the evolution of the International Institute of Tropical Forestry and activities that have influenced present day forest entomology research and USDA-Forest Service cooperative forest health programs in Puerto Rico.
\end{abstract}

Key words: International Institute of Tropical Forestry, Luquillo Experimental Forest, USDA-Forest Service, forest entomology, forest health

\section{RESUMEN}

El Instituto Internacional de Dasonomía Tropical: Antecedentes e influencia actual sobre la entomología forestal en Puerto Rico

Una sinopsis de la evolución del Instituto Internacional de Dasonomía Tropical y las actividades que han influido en la actualidad en la investigación forestal entomológica y en los programas cooperativos de salud de los bosques del USDA-Servicio Forestal en Puerto Rico.

Palabras clave: Instituto Internacional de Dasonomía Tropical, Bosque Experimental de Luquillo, Servicio Forestal, entomología forestal, salud forestal

\section{INTRODUCTION}

This paper provides a brief overview of the evolution of forest entomology research and programs at the International Institute of Tropical Forestry. It is not intended to be a comprehensive documentation of the history of the Institute.

Three distinct phases of forest entomology activity have been conducted under the auspices of the International Institute of Tropical Forestry. During the first phase, from 1920 through the $1950 \mathrm{~s}$, the focus was on economic entomology and systematics. The second phase, from 1960 through the early 1990s, saw a shift towards insect ecology and

${ }^{1}$ Presented at Entomology Symposium: Legacy of the International Institute of Tropical Forestry (IITF) 75th Anniversary, March 17-18, 2017, San Juan, P.R.

${ }^{2}$ Entomologist. USDA-Forest Service, International Institute of Tropical Forestry, San Juan, PR 00926. 
systematics. The most recent phase of entomological works began in mid-1990s and continues to the present. This period is characterized by expanded work in insect ecology and the emergence of applied entomology with cooperative forest health partnerships.

$1920 s-1950 s$

The International Institute of Tropical Forestry has been conducting forestry research since 1939 . Originally designated as an experimental station by the McSweeney-McNary Forest Research Act of 1928, it was later designated as a Tropical Experiment Station in 1938. The Tropical Experiment Station began to support the work of Leslie Holdridge and Frank Wadsworth for tree regeneration plots located in the Luquillo Experimental Forest (Wadsworth and Lugo, 1989). It was at this time that the need for economic forest entomology was recognized due to the variety of insect problems associated with tree nurseries and tree plantations. In response to this need, the first forest insect surveys that included assessments of their effects and control recommendations were reported (Martorell, 1938; Pérez, 1938).

During this time span, the Tropical Experiment Station provided technical information for the management of public and privatelyowned forests in Puerto Rico and the U.S. Virgin Islands. This information was regularly reported through the widespread distribution of the journal Caribbean Forester. In addition, there were other important entomology publications from this time that advanced the knowledge and understanding of forest-related insects in Puerto Rico. The most notable of these include: The Insects of Puerto Rico (1-4) (Wolcott, 1936, 1948); An ecological survey of the fresh water insects of Puerto Rico (García-Díaz, 1938); and A Survey of the Forest Insects of Puerto Rico (Martorell, 1945). Many other works dedicated to economic entomology and systematics were also undertaken and published. However, by the end of the 1950 s, there was a notable shift from economic entomology and systematics towards gaining a wider understanding of the interrelationships between insect populations and the forest.

$1960 \mathrm{~s}-1990 \mathrm{~s}$

The period 1960 through the early 1990s was a time of administrative change at the Tropical Experiment Station. The direction and emphasis of forest research conducted under the auspices of the Tropical Experiment Station began to shift towards an ecological-landscape model. During this period, investigations into the ecological effects of forest disturbances, insect ecology studies, and field surveys of forest insects were undertaken. 
In 1961, the Tropical Experiment Station was renamed the Institute of Tropical Forestry. It reported directly to the USDA Washington, DC office. Soon after, the U.S. Atomic Energy Commission initiated a study to measure the effects of forest disturbance on the forest ecosystem at the Luquillo Experimental Forest. This study was concerned with the effects of induced gamma irradiation on tropical forests. The aim of this research was to observe how the forest responds as a system when under stress (Odum and Pigeon, 1970). One component of this study included extensive insect surveys conducted before and after the irradiation disturbance. Changes in insect populations and distribution (in addition to other observations) were empirically analyzed and evaluated regarding the effects of the corresponding changes in the ecology of the irradiated forest.

Other ecology-based research projects initiated during this time were The Forest Nutrient Cycling and Energy Flow Study in Luquillo Experimental Forest (1970s) and the Long-Term Ecological Research Studies at El Verde in Río Grande and Bisley Watershed near the barrio of Sabana in Luquillo, Puerto Rico (1980s). The purpose of these studies was to measure changes in forest ecology that occur over an extended period in response to anthropogenic and non-anthropogenic forest disturbances. Arthropod populations and diversity are included as a measurable variable in these ecological research efforts.

In addition to these long-term forest ecology studies, there were numerous research efforts on forest insect ecology, population dynamics and systematics. These works include: The Food Web of a Tropical Rain Forest (Reagan and Waide, 1996); Insects of the Luquillo Mountains, Puerto Rico (Torres, 1994); and various publications that address insect colonization following forest disturbances (Torres, 1988, 1992a), and taxonomic descriptions of several insect genera (Willig et al., 1993; Torres, 1992b).

In 1978, the administration of the Institute of Tropical Forestry was transferred to the USDA Forest Service, Southern Forest Experiment Station, and officially designated as Research Work Unit SO-4151 (1985-1993). The Southern Forest Experiment Station provided professional and technical personnel who participated in forest research and regular field surveys of forest insects, diseases and their effects.

From 1960 through 1994, forest research was characterized by a distinct movement towards understanding ecological interrelationships among the various components that define a forest ecosystem. The study of insects, an important component of most forest communities, advanced to a level where forest entomology was better defined and supported by the gains from these research and field survey efforts. 
Mid-1990s - Present

The Institute of Tropical Forestry was officially designated as the International Institute of Tropical Forestry in 1993. No longer part of the USDA Southern Experiment Station, the International Institute of Tropical Forestry set its own mission: Develop and deliver scientific knowledge that contributes to the conservation of forests, wildlife, and watersheds of tropical forests in the context of environmental and land use change.

In addition, the International Institute of Tropical Forestry developed a vision for the future:

- Maximize the human factor in our programs and collaborations

- Increase collaboration within the Institute and with outside organizations

- Integrate all Institute programs in a way that is complementary to one another.

- Work within the strategic goals of the U.S. Department of Agriculture and the U.S. Forest Service

In keeping with its commitment to the mission and vision, the International Institute of Tropical Forestry undertook the Ecological Gradient Analysis Study and other long-term research projects. The Ecological Gradient Analysis Study was initiated in 2000 and continues today. One objective of this study is to measure the effects of anthropogenic and non-anthropogenic disturbances on forest ecosystems. This research project will yield valuable insights for evaluating ecosystem and species response to disturbances along an ecological gradient in a tropical landscape. As one of its components, it includes an analysis of these effects on forest litter invertebrates.

After the year 2000, significant research efforts on the effects of soil arthropods on litter decay in tropical wet and dry forests were initiated and continue today. These studies include non-anthropogenic effects on soil fauna, soil ecological interactions, biodiversity and functioning (Wall et al., 2011); the effects of millipedes on the decay of litter of varying lignin content (González et al., 2012); and the response of litter invertebrate communities to canopy loss and debris deposition in a tropical forest (Richardson et al., 2010).

In 1993, an additional program, State and Private Forestry, which includes the Forest Health Program, became part of the International Institute of Tropical Forestry. A primary goal of the Forest Health Program is to provide cooperative assistance in forest research and technology development to state and private forest 
landowners. The Forest Health Program works within the framework of the USDA-Forest Service strategic goals to protect forests from harmful insects and diseases and other disturbance agents including invasive plants. Projects are designed to build partnerships with local and regional cooperators to support and promote forest health activities. Some of these activities include applied research, technical training for forest insect and disease survey and identification, development and support of forest health and forest entomology programs, and public outreach and education in urban forest health projects.

Some of the current Forest Health Program partnerships at the International Institute of Tropical Forestry include: forest health conditions surveys in ten Commonwealth forests; regional monitoring of the Harrisia cactus mealybug; financial support for the Entomology Museum of the University of Puerto Rico-Mayagüez; forest health conditions survey in St. Thomas, U.S. Virgin Islands; genetic conservation of threatened Puerto Rican tree species; and several other national and regional forest health projects.

Each of these projects supports the mission and vision of the International Institute of Tropical Forestry, and the strategic plan of the USDA Forest Service by promoting the free exchange of information and cooperation among all partners by working towards the common goal of promoting forest health in the region. Valuable information concerning forest insects and diseases has helped to support the individual projects of each cooperator. In addition, this information is used to provide technical training to forest managers and technicians, support new and on-going research projects, data and specimen collections, and provide educational material for educators, students and the public.

\section{DISCUSSION}

The International Institute of Tropical Forestry has undergone many administrative and physical changes since its inception in 1939. Its mission has always been to conduct tropical forestry research, generate and disseminate knowledge for the sustainable management of tropical forests (Robinson et al., 2014). The research program will continue to evolve and be innovative. Forest entomology has always been an integral part of research and programs supported by the International Institute of Tropical Forestry. Today, the major change in this research and the support programs is the recognition that we are in the Anthropocene epoch. Research and support programs must now recognize the importance of both anthropogenic and non-anthropo- 
genic influences on forest ecology. The challenge for the next seventyfive years and beyond is to integrate these efforts so that the International Institute of Tropical Forestry can continue to enhance the outcomes of its research and collaborative programs.

\section{ACKNOWLEDGEMENTS}

The author expresses his appreciation to Dr. Ariel E. Lugo and Dr. Grizelle González of the International Institute of Tropical Forestry for reviewing this manuscript. Special recognition is given to Dr. Rosa Amelia Franqui, University of Puerto Rico-Mayagüez, for her extraordinary efforts to coordinate this event. All research conducted by the International Institute of Tropical Forestry is performed in collaboration with the University of Puerto Rico. The Entomology Symposium was supported, in part, through the Forest Health Program Grant 14DG-11120107-021.

\section{LITERATURE CITED}

García-Díaz, J., 1938. An ecological survey of the fresh water insects of Puerto Rico. J. Agric. Univ. P.R. 22(1): 43-97.

González, G., C. M. Murphy and J. Belén, 2012. Direct and indirect effects of millipedes on the decay of litter of varying lignin content. In: P. Sudarshana, M. NageswaraRao and J. R. Soneji (eds.) Tropical Forests. Intech (online publisher).

Martorell, L. F., 1938. The problem of forest entomology in Puerto Rico. Memorandum to Mr. E.W. Hadley, Forest Supervisor October 28, 1938. Unpublished 26 p.

Martorell, L. F., 1945. A survey of the forest insects of Puerto Rico. J. Agric. Univ. P.R. 29: 69-608.

Odum, H. T. and R. F. Pigeon, 1970. A tropical rainforest: A study of irradiation and ecology at El Verde, Puerto Rico. University of North Carolina. E129-E169.

Pérez, M. A., 1938. Notes about forest entomology. Memorandum to L.R. Holdridge, Asst. Forester, January 13, 1938. Unpublished $12 \mathrm{p}$.

Reagan, D. P. and R. B. Waide (eds), 1996. The Food Web of a Tropical Rain Forest. The University of Chicago Press. 623 pp.

Richardson, B. A., M. J. Richardson, G. González, A. B. Shiels and D. S. Srivastava, 2010. A canopy trimming experiment in Puerto Rico: the response of litter invertebrate communities to canopy loss and debris deposition in a tropical forest subject to hurricanes. Ecosystems 13: 286-301.

Robinson, K. J. Bauer and A. E. Lugo, 2014. Passing the baton from the Tainos to tomorrow. USDA, Forest Service, International Institute of Tropical Forestry. FS-862 $196 \mathrm{p}$.

Torres, J. A., 1994. Insects of the Luquillo Mountains, Puerto Rico. USDA, Forest Service, Southern Forest Experimental Station. General Technical Report SO-105 55 p.

Torres, J.A., 1992a. Lepidoptera outbreaks in response to successional changes after the passage of hurricane Hugo in Puerto Rico. Journal of Tropical Entomology 8: 285-298.

Torres, J. A., 1992b. Los Himenópteros de la Isla Mona. Acta Científica 6(1-3): 87-102.

Torres, J. A., 1988. Tropical cyclones effects on insect colonization and abundance in Puerto Rico. Acta Cientifica 2(1): 40-44.

Wadsworth, F. H. and A. E. Lugo, 1989. The Institute of Tropical Forestry: Fifty years of regional forestry leadership. Acta Cientifica 3(2-3): 127-133. 
Wall, D. A., G. González and B. L. Simmons, 2011. Seasonally dry forest soil biodiversity and functioning, pp 61-70, In: R. Dirzo, H.S. Young, H.A. Mooney and G. Ceballos (eds.). Seasonally Dry Tropical Forests, Ecology and Conservation. Washington, D.C., Island Press.

Willig, M. R., E. A. Sandlin and M. R. Gannon, 1993. Structural taxonomic components of habitat selection in the Neotropical floivore Lamponius portoricensis (Phasmatodea: Phasmatidae). Environmental Entomology 22(3): 634-631.

Wolcott, G.N., 1936. Insectae Borinquensis. J. Agric. Univ. P.R. 20(1): 1-627.

Wolcott, G.N., 1948. The Insects of Puerto Rico. J. Agric. Univ. P.R. 31(4): 1-975. 